\title{
Development Status of a Power Processing Unit for Low Power Ion Thrusters
}

Luis R. Piñero

Glenn Research Center, Cleveland, Ohio

Glen E. Bowers

Akima Corporation, Fairview Park, Ohio

Eric M. Lafontaine

Univeristy of Puerto Rico, Mayagüez, Puerto Rico 
Since its founding, NASA has been dedicated to the advancement of aeronautics and space science. The NASA Scientific and Technical Information (STI) Program Office plays a key part in helping NASA maintain this important role.

The NASA STI Program Office is operated by Langley Research Center, the Lead Center for NASA's scientific and technical information. The NASA STI Program Office provides access to the NASA STI Database, the largest collection of aeronautical and space science STI in the world. The Program Office is also NASA's institutional mechanism for disseminating the results of its research and development activities. These results are published by NASA in the NASA STI Report Series, which includes the following report types:

- TECHNICAL PUBLICATION. Reports of completed research or a major significant phase of research that present the results of NASA programs and include extensive data or theoretical analysis. Includes compilations of significant scientific and technical data and information deemed to be of continuing reference value. NASA's counterpart of peerreviewed formal professional papers but has less stringent limitations on manuscript length and extent of graphic presentations.

- TECHNICAL MEMORANDUM. Scientific and technical findings that are preliminary or of specialized interest, e.g., quick release reports, working papers, and bibliographies that contain minimal annotation. Does not contain extensive analysis.

- CONTRACTOR REPORT. Scientific and technical findings by NASA-sponsored contractors and grantees.
- CONFERENCE PUBLICATION. Collected papers from scientific and technical conferences, symposia, seminars, or other meetings sponsored or cosponsored by NASA.

- SPECIAL PUBLICATION. Scientific, technical, or historical information from NASA programs, projects, and missions, often concerned with subjects having substantial public interest.

- TECHNICAL TRANSLATION. Englishlanguage translations of foreign scientific and technical material pertinent to NASA's mission.

Specialized services that complement the STI Program Office's diverse offerings include creating custom thesauri, building customized data bases, organizing and publishing research results ... . even providing videos.

For more information about the NASA STI Program Office, see the following:

- Access the NASA STI Program Home Page at http://www.sti.nasa.gov

- E-mail your question via the Internet to help@sti.nasa.gov

- Fax your question to the NASA Access Help Desk at (301) 621-0134

- Telephone the NASA Access Help Desk at (301) 621-0390

- Write to:

NASA Access Help Desk NASA Center for AeroSpace Information 7121 Standard Drive Hanover, MD 21076 
NASA/TM-2000-210383

\section{Development Status of a Power Processing Unit for Low Power Ion Thrusters}

Luis R. Piñero

Glenn Research Center, Cleveland, Ohio

Glen E. Bowers

Akima Corporation, Fairview Park, Ohio

Eric M. Lafontaine

University of Puerto Rico, Mayagüez, Puerto Rico

Prepared for the

36th Joint Propulsion Conference and Exhibit

sponsored by the American Institute of Aeronautics and Astronautics

Huntsville, Alabama, July 16-19, 2000

National Aeronautics and

Space Administration

Glenn Research Center 
Available from

NASA Center for Aerospace Information 7121 Standard Drive

Hanover, MD 21076

Price Code: A03
National Technical Information Service 5285 Port Royal Road Springfield, VA 22100 Price Code: A03

Available electronically at http://gltrs.grc.nasa.gov/GLTRS 


\title{
DEVELOPMENT STATUS OF A POWER PROCESSING UNIT FOR LOW POWER ION THRUSTERS
}

\author{
Luis R. Piñero \\ National Aeronautics and Space Administration \\ Glenn Research Center \\ Cleveland, Ohio \\ Glen E. Bowers \\ Akima Corporation \\ Fairview Park, Ohio \\ Eric M. Lafontaine \\ University of Puerto Rico \\ Mayagüez, Puerto Rico
}

\begin{abstract}
$\underline{\text { Abstract }}$
An advanced breadboard PPU for a low power ion propulsion system incorporating mass reduction techniques was designed and fabricated. As a result of similar output current requirements, the discharge supply was also used to provide the neutralizer heater and discharge heater functions by using three relays to switch the output connections. This multi-function supply reduces to four the number of power converters needed to produce the required six electrical outputs. Switching frequencies of 20 and $50 \mathrm{kHz}$ were chosen as a compromise between the size of the magnetic components and switching losses. The advanced breadboard PPU is capable of a maximum total output power of $0.47 \mathrm{~kW}$. Its component mass is $0.65 \mathrm{~kg}$ and its total mass $1.9 \mathrm{~kg}$. The total efficiency at full power is 0.89 .
\end{abstract}

\section{Introduction}

Ion propulsion systems have the advantage of high specific impulse when compared to chemical and other electric propulsion systems. This can lead to reductions in launch vehicle class, increased payload mass fraction, and/or spacecraft life. There is a potential need for high specific impulse propulsion for small spacecraft. Applications that might benefit from this technology include Earthorbit magnetospheric mapping satellite constellations, low Earth-orbit satellites, geosynchronous Earth-orbit (GEO) satellite northsouth stationkeeping, and asteroid orbiters using spacecraft of 50 to $500 \mathrm{~kg}$ and within the order of 0.2 to $0.5 \mathrm{~kW}$. ${ }^{1}$ Some inherent problems of using electric propulsion with small spacecraft include cost, limited power, volume, and thermal control capacity. This makes simplicity, size, weight and high efficiency critical requirements for the implementation of this technology.
Development of a low power xenon ion thruster continues at NASA Glenn Research Center (NASA-GRC) under NASA's On-Board Propulsion Program. ${ }^{2-3}$ This design builds on the NSTAR $30-\mathrm{cm}$ thruster, incorporating features such as a ring-cusp magnetic circuit, partial-conic discharge chamber, and non-ferromagnetic materials. ${ }^{4} \quad$ Figure 1 shows a picture of an engineering model thruster.

In addition to the thruster, a breadboard power processing unit (PPU) was initially developed for the $0.2 \mathrm{~kW}$-class ion propulsion system. ${ }^{5}$ Low mass and volume, high efficiency and simplicity were the major design drivers. The PPU would supply the six electrical outputs required by the ion thruster using a nominal input voltage of $28 \pm 4$ $\mathrm{V}_{\mathrm{DC}}$, since the small spacecraft for which this system is targeted are anticipated to have unregulated low voltage busses. The breadboard PPU was designed, fabricated, successfully tested on resistive loads, and integrated with a laboratory model thruster. Figure 2 shows a picture of the breadboard PPU. Six power converters, switching at $20 \mathrm{kHz}$, were used to produce the six required outputs. The beam supply, which processes 65 to 80 percent of the total thruster power, has an efficiency of up to 91 percent while the total PPU efficiency was in excess of 89 percent at a maximum power of $0.3 \mathrm{~kW}$. The component mass was $1.4 \mathrm{~kg}$ and the total mass of the breadboard was approximately $2.2 \mathrm{~kg}$.

To comply with revised output power requirements of up to $0.47 \mathrm{~kW}$, an advanced breadboard PPU was designed and fabricated based on the prior design. This paper documents the design process and performance characteristics of the advanced breadboard PPU. It also includes the results of resistive load tests for efficiency and regulation. 


\section{$\underline{\text { PPU Design }}$}

Ion PPUs can be very complex. A typical PPU includes up to six power supplies and electronics for additional functions as shown in Figure 3. The beam and the accelerator supplies provide high voltages to accelerate the ions. The discharge supply provides current to the discharge cathode to ionize the xenon propellant. The neutralizer keeper supply provides current to the neutralizer cathode to neutralize the ion beam. The heater supplies raise the temperature of the cathode to emission temperature during ignition. Finally, the housekeeping supply provides power to the pulsewidth-modulation (PWM), recycle, telemetry, and control circuits.

Low mass and high efficiency are the typical design drivers for any PPU. However, the power level and application could weigh these differently. For low power systems, low mass tends to be slightly more important than high efficiency. Additionally, cost and complexity should be low to appeal commercial users.

The mass of a PPU is mainly determined by the number of power converters, the switching frequency, and the power level. In a hardswitching converter design, increasing the switching frequency to reduce mass is only beneficial to the point where the switching losses become the primary loss mechanism. Beyond this point, soft-switching or resonant designs are needed to reduce switching losses. However, these techniques add complexity to the converter.

Major impact on PPU mass can be obtained by using multiple output power supplies or even more by using multiple function power supplies. There are many ways of implementing these two techniques and several have been documented. ${ }^{6-9}$ One multiple output option includes combining the beam and accelerator outputs and the discharge and neutralizer outputs. However, this approach makes the two outputs track each other making it difficult to throttle the thruster. A solution to this problem is adding a secondary regulation stage for one of the outputs which can become as complex as having separate converters for each output. Another multiple function supply technique consists in using the neutralizer or discharge supplies to provide heater power. ${ }^{9}$ The main difficulty of this technique is that it requires some switches for the converter output and it could increase the duration of the thruster starting sequence.
Figure 4 shows a block diagram of the NASAGRC advanced breadboard PPU. It consists of four power supplies to operate the thruster, a housekeeping power supply, a control circuit to sequence the power supplies, and a recycle circuit to extinguish arcs in the thruster during operation. Since the NASA-GRC $8-\mathrm{cm}$ ion thruster has very similar input current specifications for the discharge and heaters, it was decided to use a multi-function discharge supply to also power the cathode and neutralizer heaters. This design reduced by two the number of power converters in the PPU compared to the prior design. Table 1 summarizes the output specifications of all the power supplies. The maximum total output power of the unit is $0.47 \mathrm{~kW}$. Another difference between the advanced and the prior PPU design is a higher switching frequency of $50 \mathrm{kHz}$ on all the power converters, except the beam supply, to reduce the size of the magnetic components while maintaining low switching losses.

The PPU was built on five multi-layered printed circuit boards (PCB) with surface mount components. One $\mathrm{PCB}$ contains the discharge supply including the output relays. Another includes both the neutralizer and accelerator supplies. The beam supply consists of two PCBs. One houses the PWM circuit, the housekeeping supply, and the recycle circuit. The second includes the MOSFETs, output rectifiers, and filters. The fifth board will include the control circuit. The beam power transformer, which is the largest and heaviest component, is mounted to the side-wall of the aluminum enclosure that houses the PPU to provide a good heat-sink. A photograph of the advanced breadboard PPU is shown in Figure 5.

Beam Supply

The most important converter in the PPU is the beam supply. This is the converter that generates high output voltage and processes up to 80 percent of the total power in the PPU. High efficiency on the beam supply is critical to obtain high total efficiency in the PPU.

A full-bridge topology was selected because of the power level for this converter. A simplified diagram of the topology is shown in Figure 6. Even though rather complex when compared to other switching topologies, the full-bridge topology is robust for high power applications. It also requires a simpler transformer with good core 
utilization factor, lower voltage transistors on the power stage, and could be modified to implement soft-switching techniques. The high output voltage was obtained by four secondary windings connected in series reducing the required voltage rating for output diodes. A switching frequency of $20 \mathrm{kHz}$ was used on this converter to reduce switching losses that can be severe at higher switching frequencies and to minimize the effect of parasitic components caused by the high step-up ratio of the power transformer.

The full-bridge topology uses peak current-mode PWM control on MOSFETs 2 and 4 and 50 percent duty-cycle on MOSFETs 1 and 3. This is accomplished by a circuit built of discrete components including OPAMPs, logic gates, and flip/flops. Feedback isolation is implemented using a differential amplifier for output voltage and a current transformer for primary current. High side drivers with a charge pump circuit provide gate drive for the power MOSFETs.

The power transformer was built using a 3C85 ferrite EC core. The primary was wound using multiple strands of magnet wire to minimize skin effect and each of the four secondaries were wound in a single layer to minimize winding capacitance. Both, input and output filter inductors were wound in a $3 \mathrm{~F} 3$ ferrite pot core.

\section{Discharge and Neutralizer Keeper Supplies}

The discharge supply follows the beam supply in power output. Even though its power fraction is smaller than the beam supply, it is still important to maximize its efficiency. A forward topology with a reset winding was selected for the discharge supply based on the power level and its simplicity. A simplified diagram of this topology is shown in Figure 7. The forward converter requires only one switching transistor compared to two required by a push-pull or a half-bridge or four required by a full-bridge. Also, it does not require high-side driving capabilities. A switching frequency of $50 \mathrm{kHz}$ was chosen to minimize mass. Current mode control PWM was used in the design for its good regulation and over-current protection. This was implemented using a commercial PWM controller which has flight heritage.

The power transformer, the input inductors, and output inductors were built using $3 \mathrm{~F} 3$ ferrite pot cores which work well for high frequency applications and have low core losses. Pot cores also offer the advantage of shielding from magnetic fields and being easy to wind and heat sink. The output current ripple specification was relaxed compared to prior designs to reduce the size of the output inductor.

Cathode ignition is triggered by an inductivelycoupled capacitor-discharge pulse ignitor used in prior programs. ${ }^{10}$ It provides a $600 \mathrm{~V}$ pulse with a duration of $10 \mu \mathrm{s}$ and a frequency of $10 \mathrm{~Hz}$. Figure 8 shows a family of ignition pulses at 24,28 , and $32 \mathrm{~V}$ input to the discharge supply.

The discharge supply is a multi-function supply providing power not only to the discharge anode but also to both the discharge and neutralizer cathode heaters. This is implemented by three high voltage relays on the output of the converter to switch the connections. To reduce stress on the relays, they are never operated while the discharge supply is on.

The neutralizer keeper supply provides current to the neutralizer anode to provide a path for electrons from the cathode to this anode to "keep" the neutralizer discharge lit and ready to neutralize the ion beam. Although, it processes less power than the discharge supply and because of similar output characteristics, the same forward topology, PWM control, magnetic core types, and ignitor circuit were used for this converter to maintain PPU simplicity.

\section{Accelerator Supply}

The accelerator supply processes very little power but at relatively high voltage. A flyback topology was chosen for this supply for its simplicity, power level, and output voltage requirements. Figure 9 shows a simplified diagram of the topology. Like the forward topology, only one switching transistor is required. Also, inherent to the flyback topology, an output inductor is not required.

Current mode control PWM was also implemented with a commercial controller and the magnetics were built with $3 \mathrm{~F} 3$ ferrite pot cores. In addition, the accelerator supply should be capable of providing a current surge of about $50 \mathrm{~mA}$ for $100 \mathrm{~ms}$ during high voltage recycle events. This avoids, during thruster ignition and recycles, loading down the power supply and causing electron backstreaming that could trigger another recycle. This is implemented by sizing the output capacitor to provide the surge requirements.

\section{$\underline{\text { Recycle and Control Circuits }}$}

Momentary short circuits in the thruster are possible during steady-state operation. A recycle circuit monitors beam power supply output. When 
high current is detected, it cycles the high voltage supplies to extinguish the short circuit. A sequential circuit based on the design for the breadboard PPUs designed at NASA-GRC for the NSTAR Program was used. ${ }^{6-8}$ This circuit is simple and has proven reliable in other designs. One additional feature is the capability of increasing neutralizer keeper current during a recycle to maintain a constant total emission current and avoid possible extinction.

A sequential circuit or state machine with three select bits is included to control and sequence the PPU outputs. The control sequences implemented are cathode conditioning, thruster ignition, throttleup, and throttle-down. A summary of these sequences is shown in Figure 10. The cathode conditioning sequence cycles the discharge power supply to provide heater outputs first to the neutralizer and then to the discharge cathode to remove impurities prior to initial operation. The thruster ignition sequence turns on the discharge supply into the neutralizer heater and then turns on the neutralizer keeper supply. Then, it switches the discharge supply into the discharge heater. This is followed by switching the discharge supply to the anode, and then turning on the discharge supply. Finally, it turns on the beam and accelerator supplies to start thrusting. The throttle-up and throttle down sequences adjust the power into the thruster by changing the supply setpoints up to eight operational levels. On the throttle-up sequence, accelerator voltage is increased first, then the beam voltage, and finally the discharge current. The throttle-down sequence decreases the output in the opposite order. This reduces the possibility of triggering a recycle during these sequences.

\section{Telemetry}

The telemetry outputs for the breadboard PPU are minimized to reduce complexity. The only telemetry included are beam voltage and current to provide the means of calculating specific impulse and thrust. This is the only telemetry that is considered critical to monitor mission progress. Discharge and neutralizer telemetry consists of bits that indicate if the output currents have exceeded certain values.

\section{Test Procedure}

The power converters were performance tested for efficiency and regulation. This was done using resistive loads and a high bandwidth power analyzer to measure voltages and currents. The power supplies were operated until thermal equilibrium was reached and then input voltage and loads were varied through the complete range. Efficiency for the individual converters was defined as the ratio of output to input power. Total PPU efficiency was calculated including housekeeping power. Load regulation was defined as the ratio of the difference between output at low and full load and the output setpoint. Line regulation was defined as the ratio of the difference between output at low and high input voltage and the output setpoint.

\section{$\underline{\text { Results and Discussion }}$}

All output specifications, according to Table 1, were verified. Both, line and load regulations were measured at better than 0.1 percent. Power conversion efficiency was measured for all the power supplies at a nominal input voltage of $28 \mathrm{~V}$. Figures 11 through 13 show the efficiencies for the beam, discharge, and neutralizer supplies. For the beam supply it was plotted as a function of output current for various output voltages and for the discharge and neutralizer supplies as a function of output voltage for multiple output currents. The beam supply has a maximum efficiency of 0.94 at $1200 \mathrm{~V}$ and $200 \mathrm{~mA}$ output. In the case of the discharge supply, efficiency reached a maximum of 0.89 at an output of $32 \mathrm{~V}$ and $1 \mathrm{~A}$. The neutralizer demonstrated efficiencies as high as 0.88 at $32 \mathrm{~V}$ and $200 \mathrm{~mA}$. Finally, the accelerator efficiency was measured to a maximum of 0.25 at $300 \mathrm{~V}$ and $1 \mathrm{~mA}$. The total efficiency of the advanced PPU including housekeeping power and operating at full power is 0.89. The efficiency at power levels representative of thruster operation at $0.3,0.2$, and $0.1 \mathrm{~kW}$ was $0.90,0.87$, and 0.84 , respectively.

\section{Conclusion}

An advanced breadboard PPU which builds on a prior design was fabricated and tested. This design includes a multi-function discharge/heater power supply that reduces to four the number of power converters required. A switching frequency of 50 $\mathrm{kHz}$ was used for the discharge, neutralizer, and accelerator supplies to reduce the size of magnetic components. However, the optimum frequency of the beam supply was $20 \mathrm{kHz}$ because of excessive switching losses. The advanced breadboard was built using five multi-layer PCB with surface mount components, installed in an aluminum chassis. A maximum total efficiency of 0.89 at maximum power of $0.47 \mathrm{~kW}$ was obtained. The component and total masses were 0.65 and $1.9 \mathrm{~kg}$, respectively. The advanced breadboard PPU was tested on resistive loads for regulation and efficiency. All design criteria were met. 
A sequential circuit that control the operation of the power supplies during cathode conditioning, thruster ignition, and throttling up and down was also designed and tested. Future work will include integrating all the power supplies and the controller into the PPU and testing with the engineering model thruster.

\section{$\underline{\text { References }}$}

1. Patterson, M. J. and Oleson, S. R., "LowPower Ion Propulsion for Small Spacecraft," AIAA Paper 97-3060, July, 1997.

2. Patterson, M. J., et al., "Scaling of Ion Thrusters to Low Power," AIAA Paper 97-098, August, 1997.

3. Patterson, M. J., "Low-Power Ion Thruster Development Status," AIAA Paper 98-3347, July, 1998.

4. Sovey, J. S., et al., "Development of an Ion Thruster and Power Processor for New Millennium's Deep Space 1 Mission," AIAA 97-2778, July 1997.
5. Piñero, L. R., et al., "Development of Power Electronics for a $0.2 \mathrm{~kW}$-Class Ion Thruster," AIAA Paper 97-099, August 1997.

6. Hamley, J. A., et al., "A $2.5 \mathrm{~kW}$ Power Processor for the NSTAR Ion Propulsion Experiment," AIAA Paper 94-3305, June 1994.

7. Hamley, J. A., et al., "Development Status of the NSTAR Ion Propulsion System Power Processor," AIAA Paper 95-2517, July 1995.

8. Hamley, J. A., et al., "NSTAR Ion Thruster and Breadboard Power Processor Functional Integration Test Results," AIAA Paper 96-2720, July 1996.

9. Rawlin, V. K., et al., "Simplified Power Processing for Inert Gas Ion Thrusters," AIAA Paper 93-2397, June 1993.

10. Sarmiento, C. J., et al., "Low Power Arcjet Thruster Pulse Ignition," AIAA Paper 87-1951, June 1987. 


\begin{tabular}{||c|c|c|c|c|c|c||}
\hline \hline & BEAM & ACCEL & DISCHARGE & NEUT & HEATERS & TOTAL \\
\hline $\begin{array}{c}\text { Input } \\
\text { Voltage }\end{array}$ & $24-32 \mathrm{~V}$ & $24-32 \mathrm{~V}$ & $24-32 \mathrm{~V}$ & $24-32 \mathrm{~V}$ & $24-32 \mathrm{~V}$ & \\
\hline $\begin{array}{c}\text { Output } \\
\text { Voltage }\end{array}$ & $600-1200 \mathrm{~V}$ & $-(300-150) \mathrm{V}$ & $16.0-32.0 \mathrm{~V}$ & $16.0-32.0 \mathrm{~V}$ & $7.0 \mathrm{~V}$ & \\
\hline $\begin{array}{c}\text { Output } \\
\text { Current }\end{array}$ & $0.07-0.3 \mathrm{~A}$ & $\begin{array}{c}0.5-1.0 \mathrm{~mA} \\
50 \mathrm{~mA} \text { surge } \\
\text { for } 100 \mathrm{~ms}\end{array}$ & $0.5-3.0 \mathrm{~A}$ & $0.2-0.5 \mathrm{~A}$ & $4.0 \mathrm{~A}$ & \\
\hline $\begin{array}{c}\text { Output } \\
\text { Power }\end{array}$ & $42-360 \mathrm{~W}$ & $75-300 \mathrm{~mW}$ & $8-96 \mathrm{~W}$ & $3.2-16 \mathrm{~W}$ & $28 \mathrm{~W}$ & $53.3-472.3 \mathrm{~W}$ \\
\hline $\begin{array}{c}\text { Reg. Mode } \\
\text { Constant } \\
\text { Voltage }\end{array}$ & $\begin{array}{c}\text { Constant } \\
\text { Voltage }\end{array}$ & $\begin{array}{c}\text { Constant } \\
\text { Current }\end{array}$ & $\begin{array}{c}\text { Constant } \\
\text { Current }\end{array}$ & $\begin{array}{c}\text { Constant } \\
\text { Current }\end{array}$ & \\
\hline $\begin{array}{c}\text { Line/Load } \\
\text { Reg. }\end{array}$ & $<1 \%$ & $<1 \%$ & $<1 \%$ & $<1 \%$ & $<1 \%$ & \\
\hline $\begin{array}{c}\text { Output } \\
\text { Ripple }\end{array}$ & $<5 \%$ & $<5 \%$ & $<10 \%$ & $<10 \%$ & $<10 \%$ & \\
\hline \hline
\end{tabular}

Table 1. Advanced Low Power Ion PPU Specifications

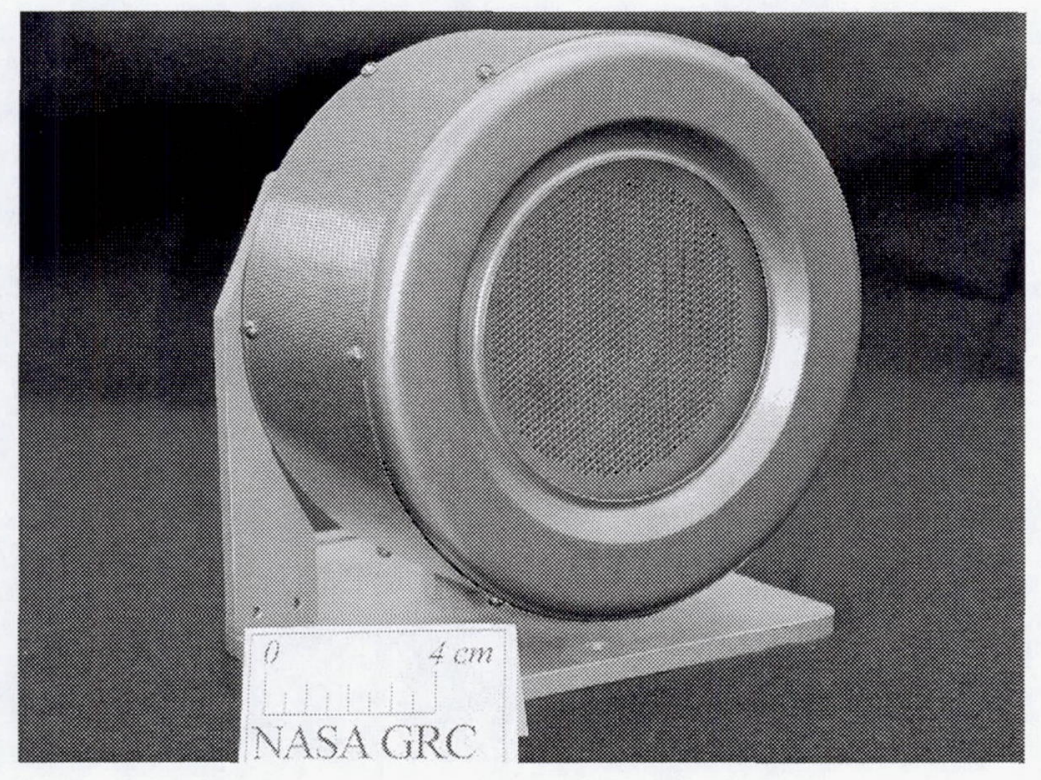

Figure 1. 8-cm Engineering Model Xenon Ion Thruster 


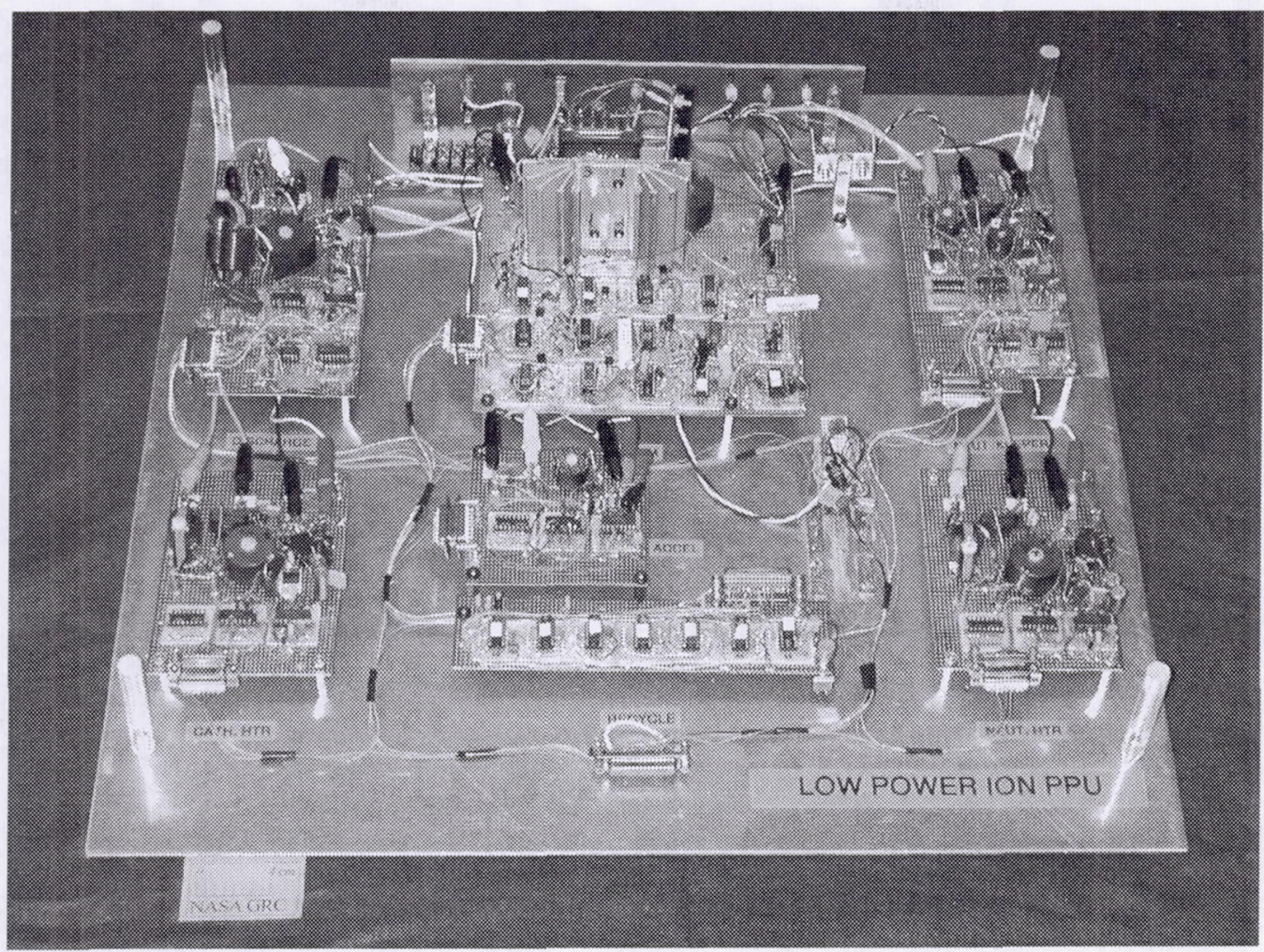

Figure 2. Low Power Breadboard PPU

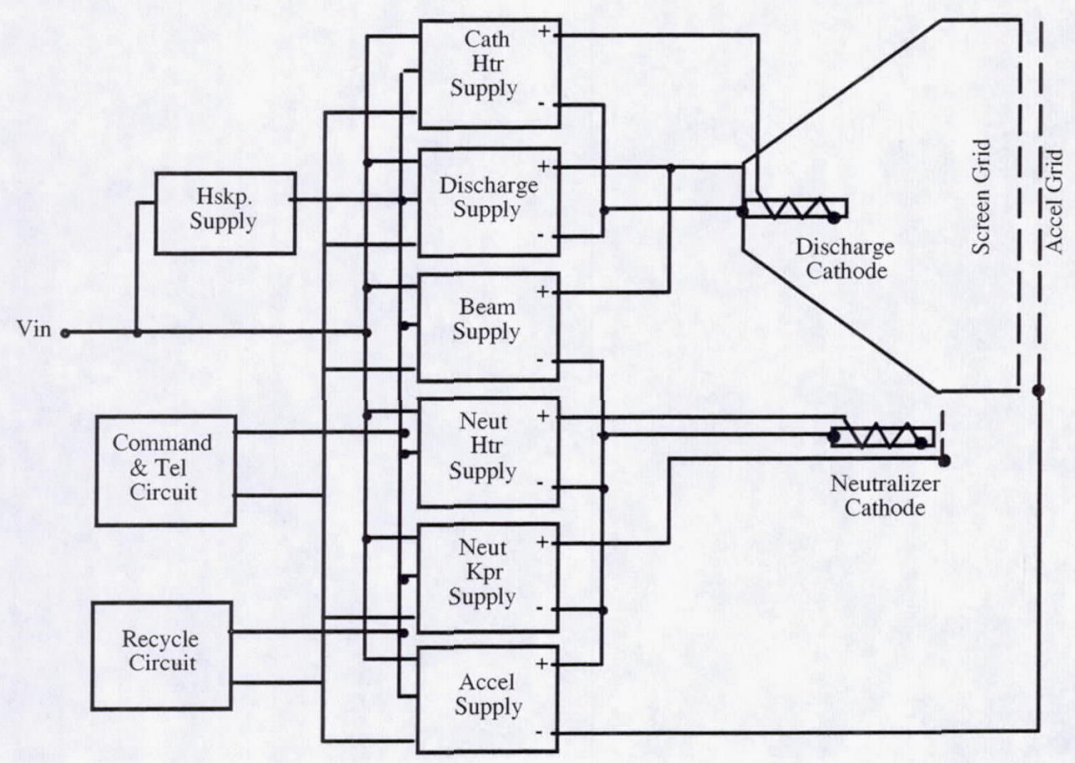

Figure 3. Ion PPU Block Diagram 


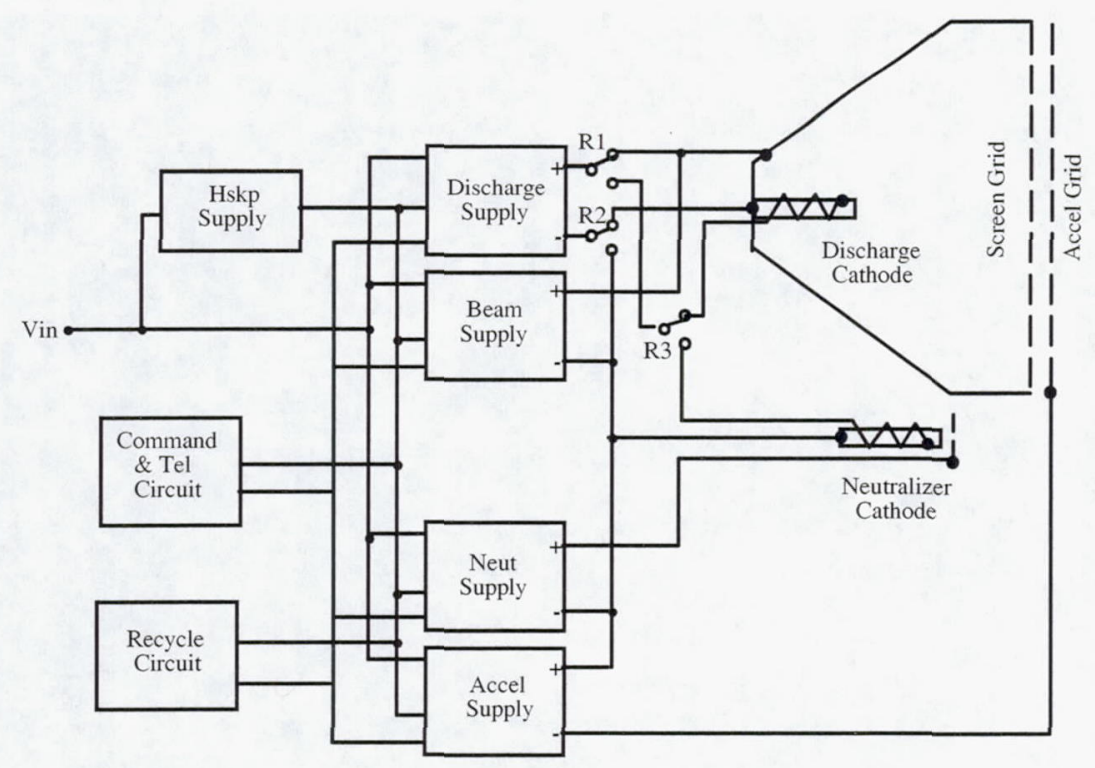

Figure 4. Advanced Ion PPU Block Diagram

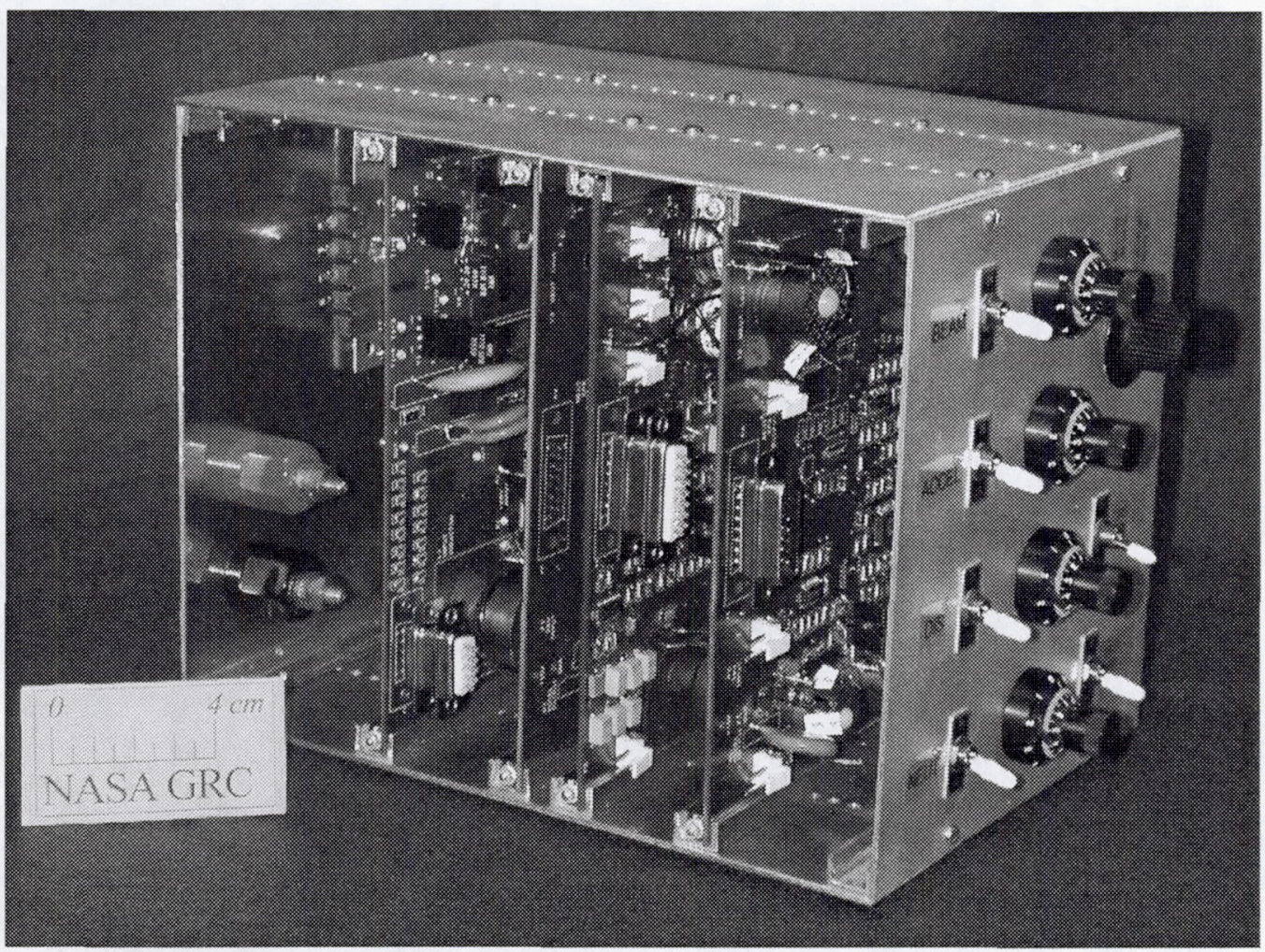

Figure 5. Advanced Low Power Breadboard PPU 


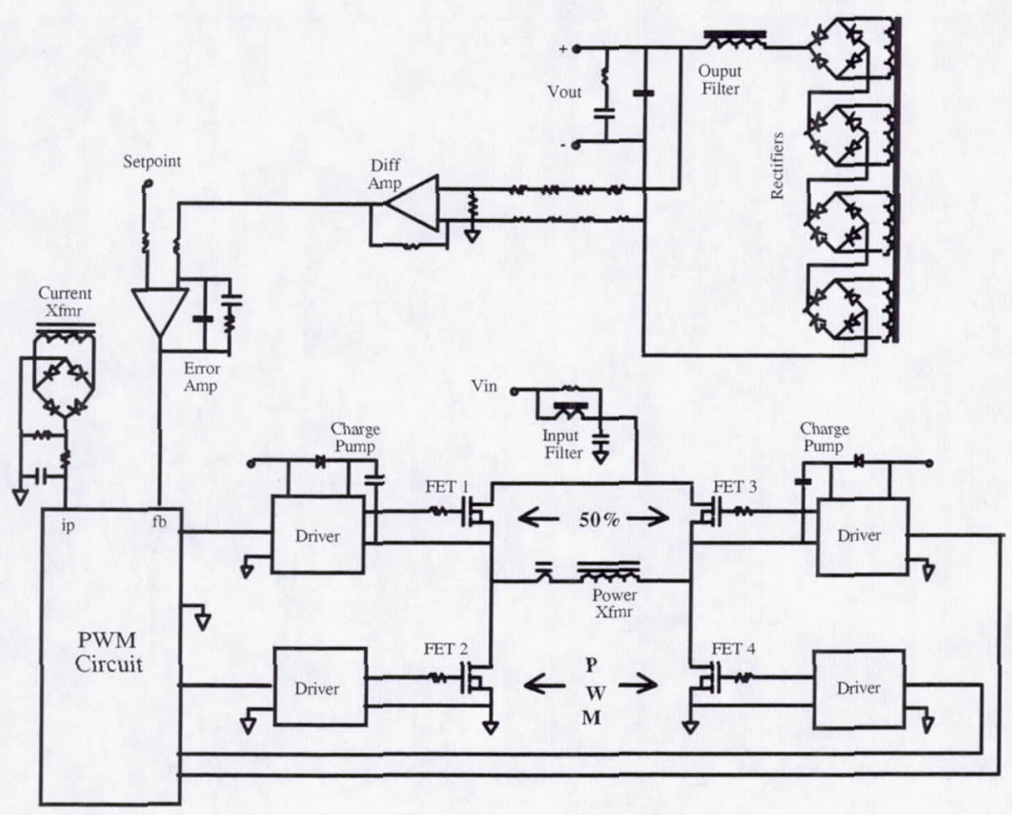

Figure 6. Full Bridge Topology Schematic

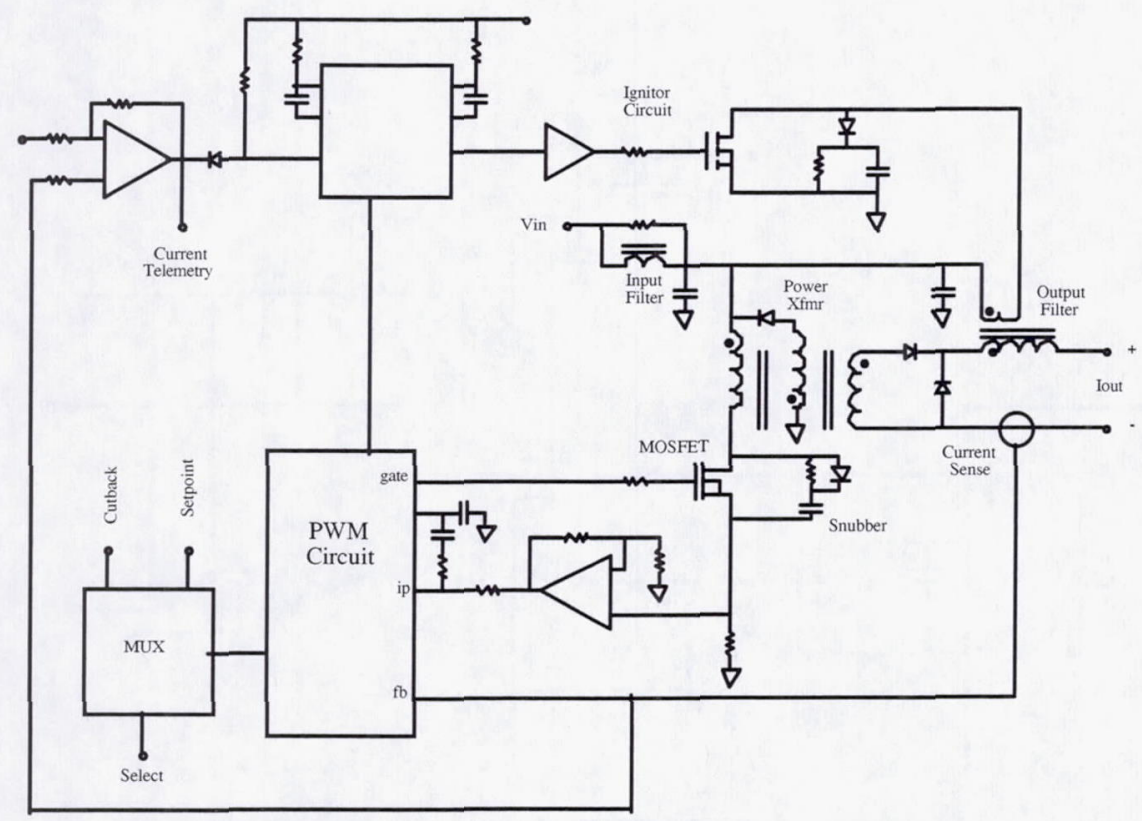

Figure 7. Forward Topology Schematic 


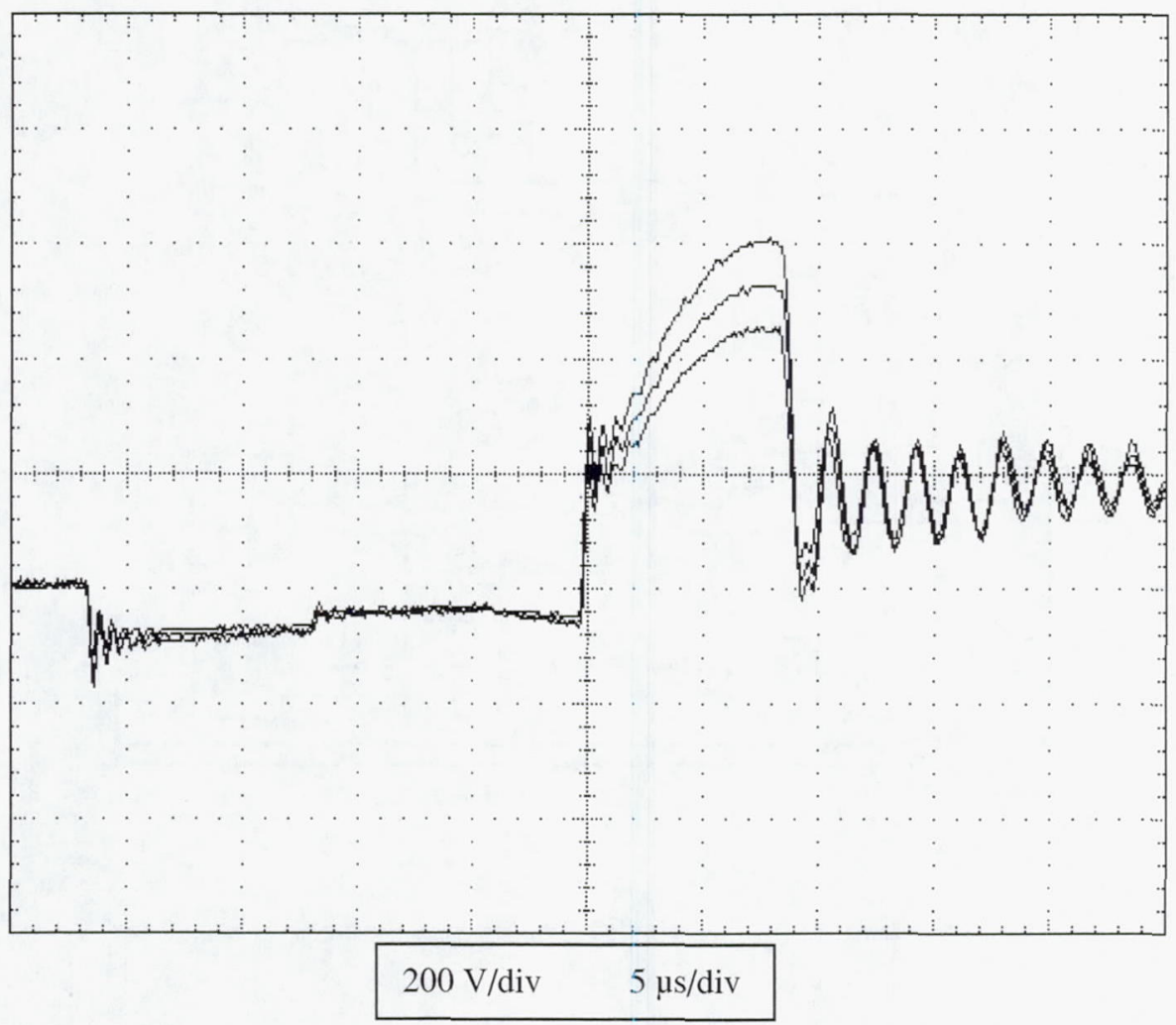

Figure 8. Family of Ignitor Pulses at 24, 28, and $32 \mathrm{~V}$ Input

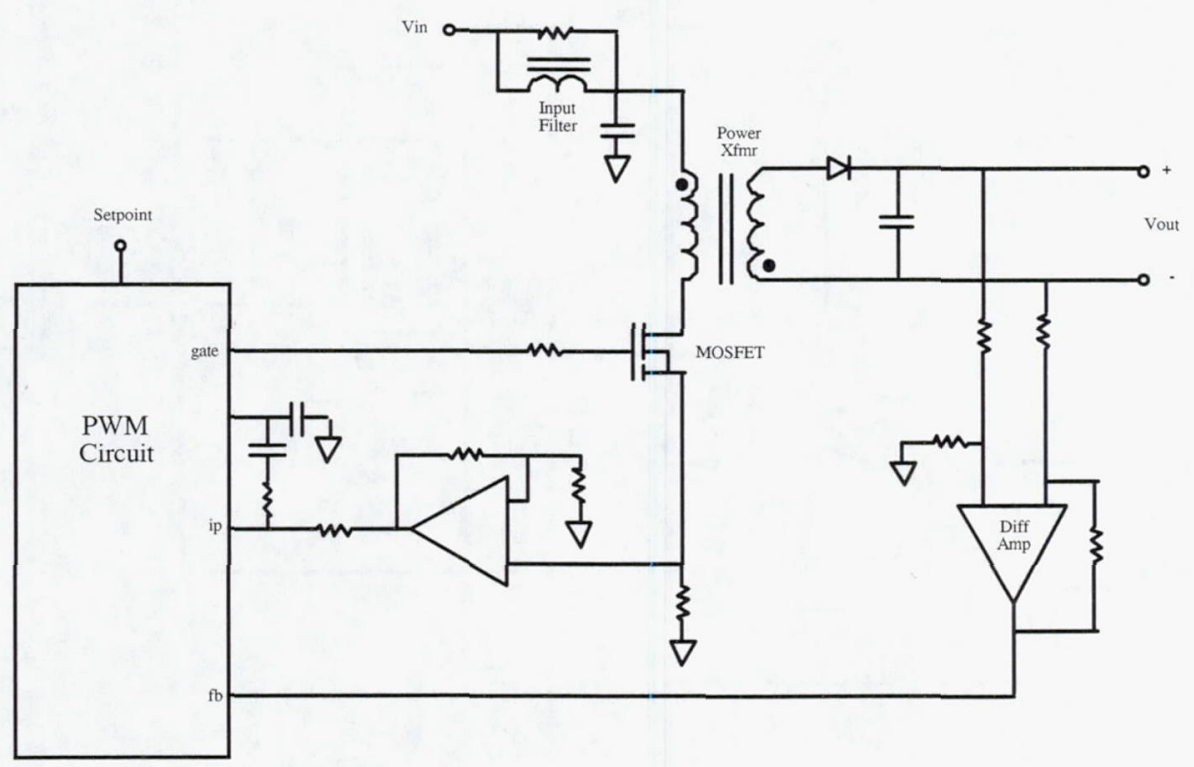

Figure 9. Flyback Topology Schematic 


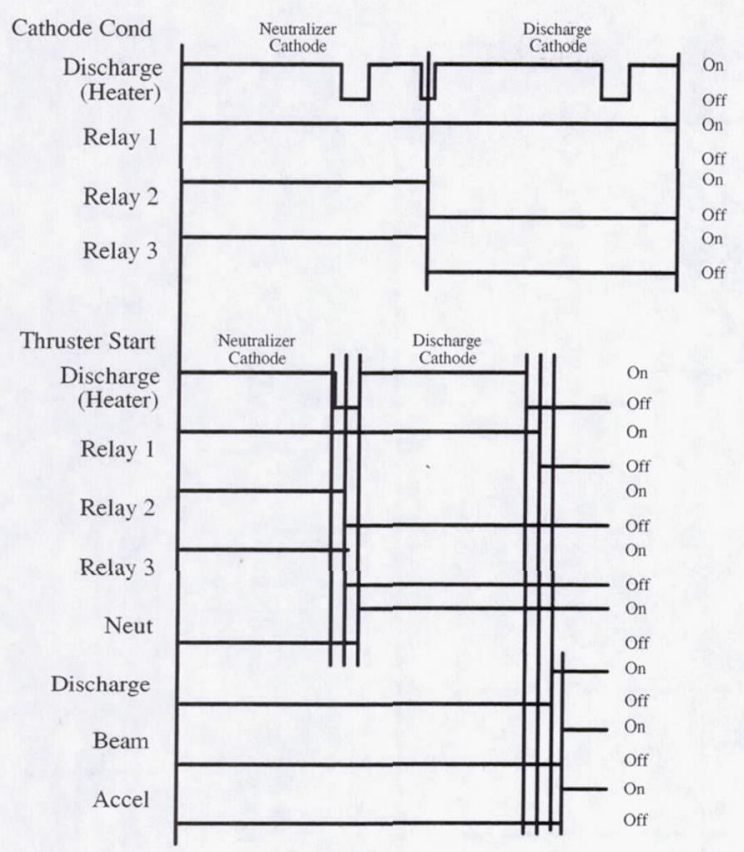

\begin{tabular}{|l|cll|}
\hline Sequence & Select & Bits \\
\hline Thruster Off & 0 & 0 & 0 \\
Cathode Cond & 0 & 0 & 1 \\
Thruster Start & 0 & 1 & 0 \\
Standby & 0 & 1 & 1 \\
Throttle Up & 1 & 0 & 0 \\
Throttle Down & 1 & 0 & 1 \\
\hline
\end{tabular}
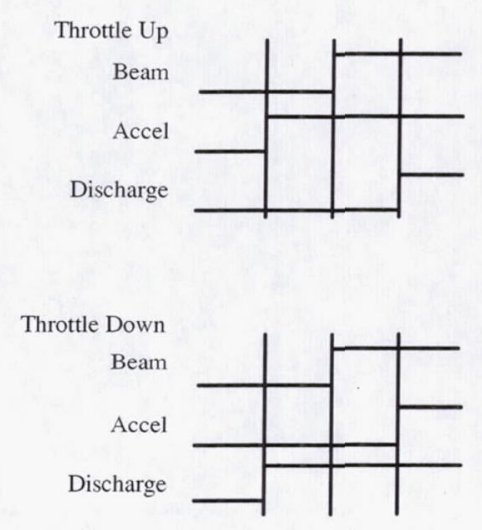

Figure 10. Controller Sequences

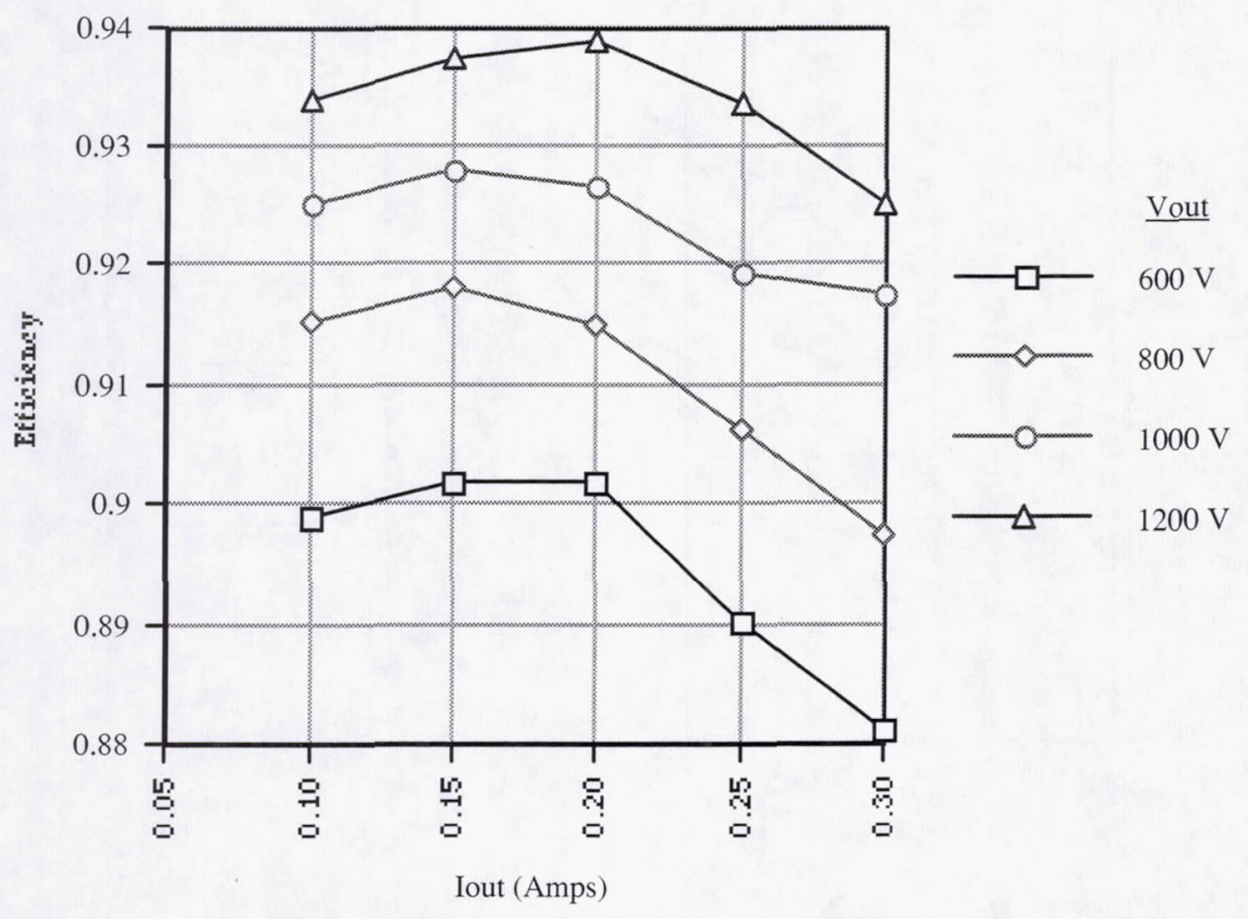

Figure 11. Beam Supply Efficiency at $28 \mathrm{~V}$ Input 


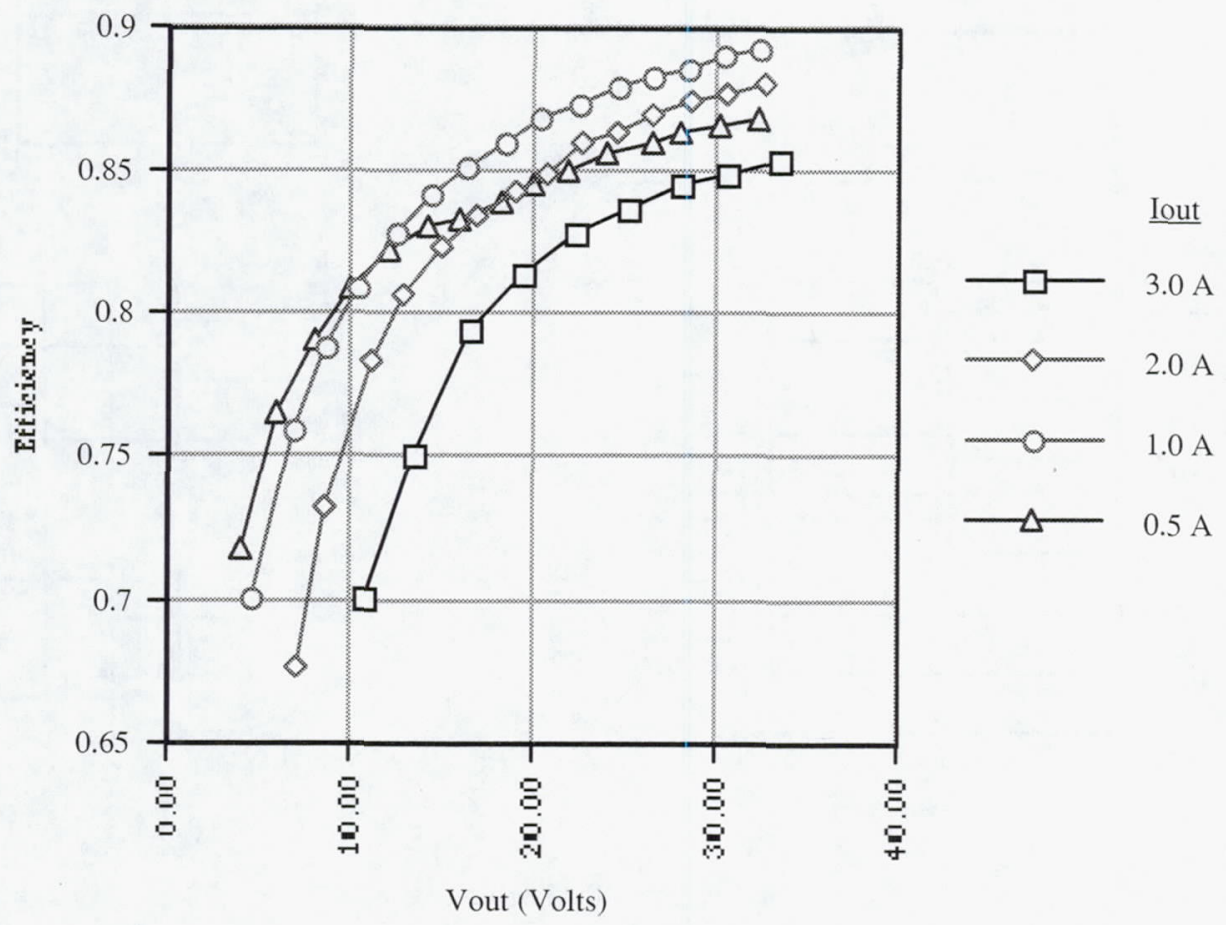

Figure 12. Discharge Supply Efficiency at $28 \mathrm{~V}$ Input

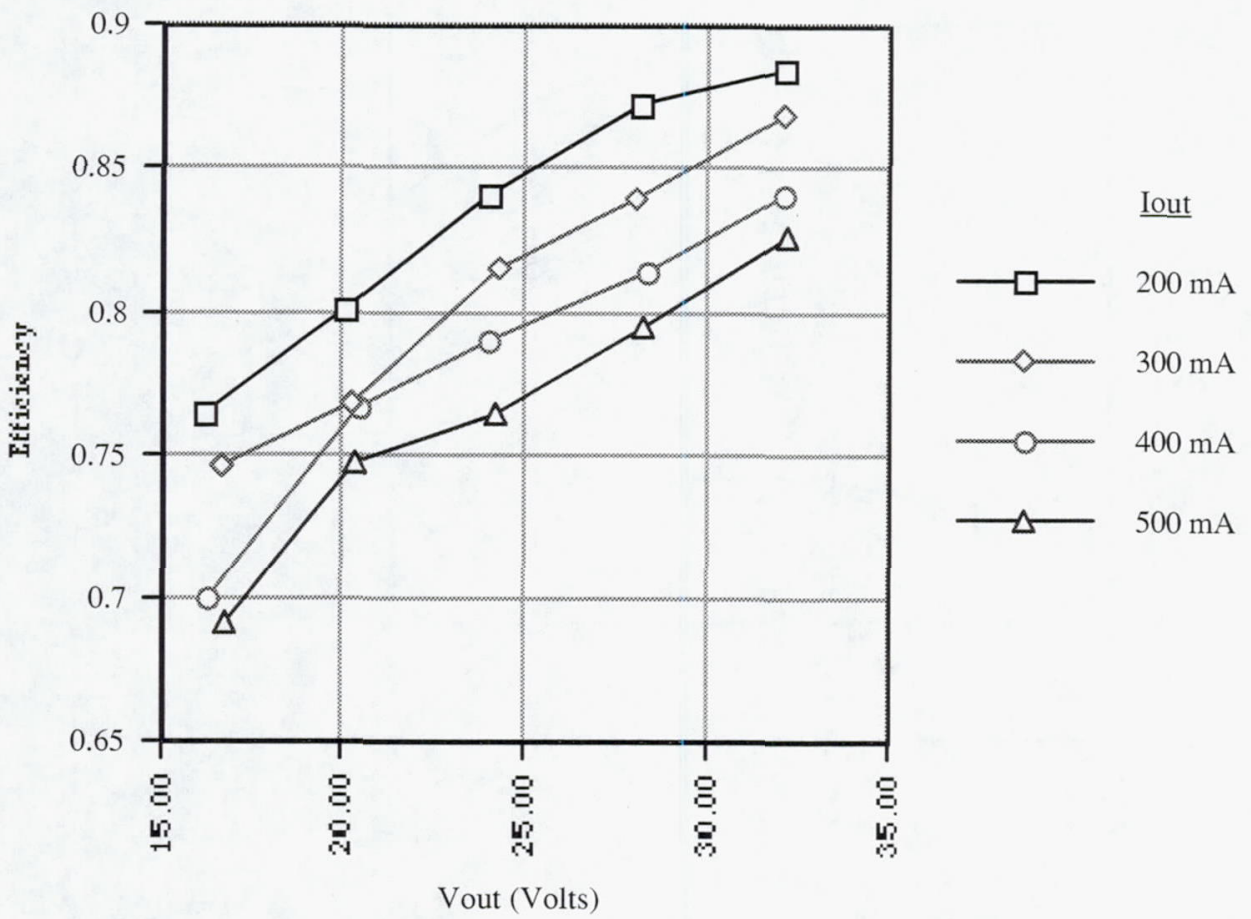

Figure 13. Neutralizer Supply Efficiency at $28 \mathrm{~V}$ Input 


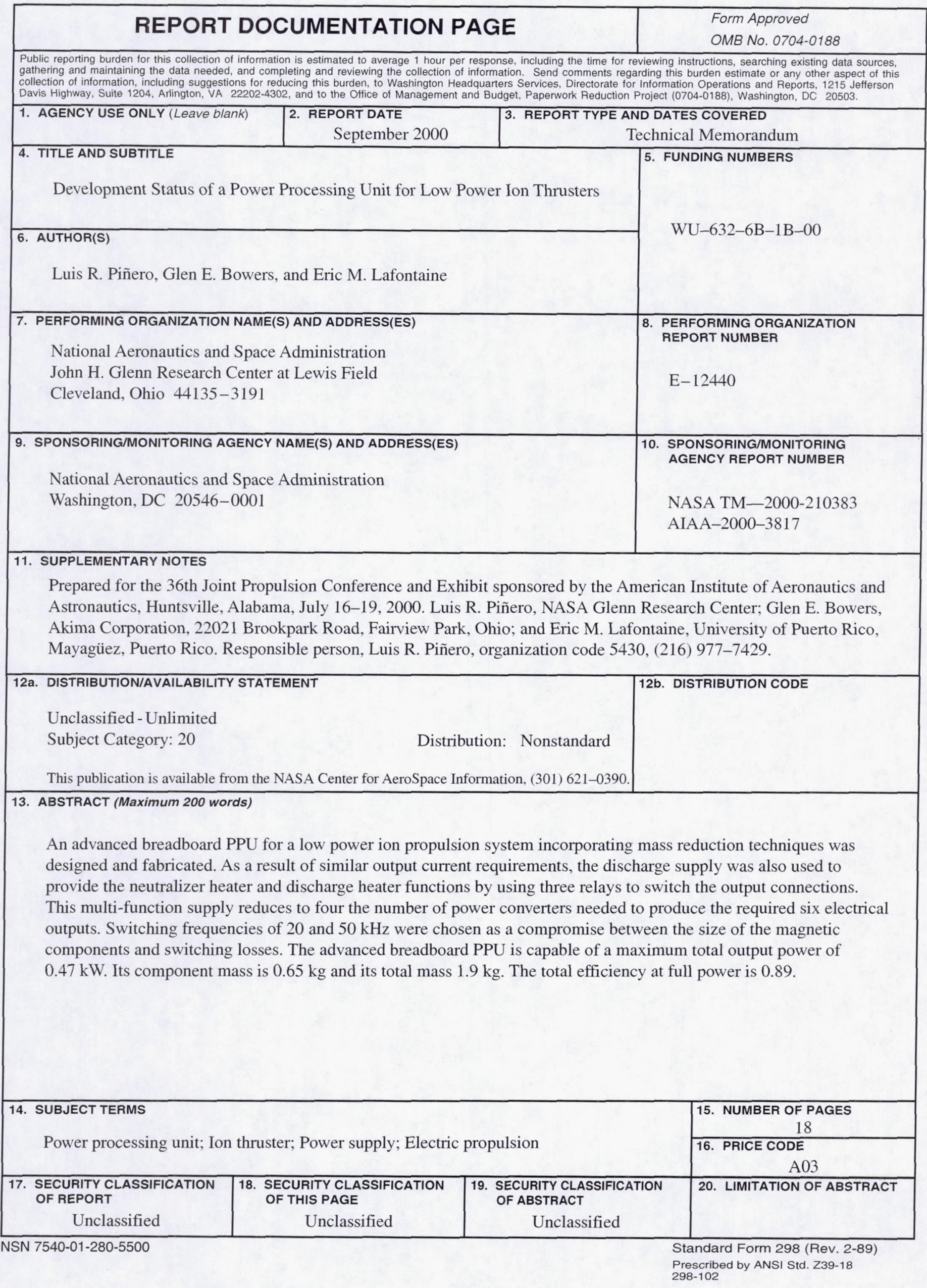

